DOI: $\underline{\text { https://doi.org/10.31933/dijemss.v3i1 }}$

Received: 7 October 2021, Revised: 17 October 2021, Publish: 27 October 2021

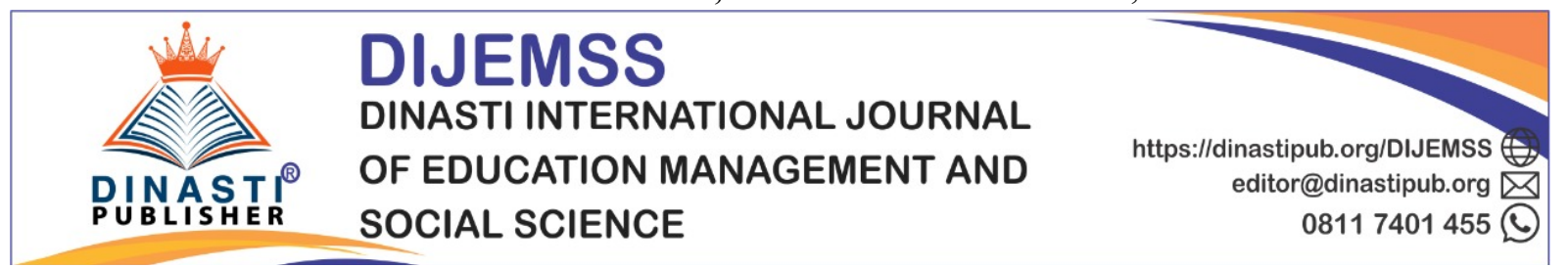

\title{
THE MEDIATING ROLE FROM WORK MOTIVATION TOWARDS THE IMPLEMENTATION OF CORPORATE GOVERNANCE AND RSUD X'S PERFORMANCE
}

\author{
Riastuti Dyah Ayu Damayanti ${ }^{1}$, Ratna Indrawati ${ }^{2}$, Mus Aida ${ }^{3}$ \\ 1) Universitas Esa Unggul, Jakarta, Indonesia, ria.nnaa28@gmail.com \\ 2) Universitas Esa Unggul, Jakarta, Indonesia, ratna.indrawati@esaunggul.ac.id \\ 3) Universitas Esa Unggul, Jakarta, Indonesia, mus.aida@,esaunggul.ac.id
}

\section{Corresponding Author: Riastuti Dyah Ayu Damayanti}

\begin{abstract}
RSUD X is a public organization which provides health services for patients and it is required to provide those services in accordance with the standards set by the Ministry of Health of the Republic of Indonesia and the Hospital Accreditation Commission and strive to implement corporate governance to optimize its performance. This research aims to analyze the affect from the implementing corporate governance and transformational leadership style to the performance of RSUD X through work motivation as an mediating variable. This research with a quantitative and survey method used the questionnaires and audit data. The population is all employees of the State Civil Apparatus at RSUD X, which are service personnel and management/administration staff. The sampling technique that used in this research was disproportionate stratified random sampling with a sample size of 200 respondents. The data analysis method through SEM-AMOS. And the research results found: There is a simultaneous and partial affect which caused by the implementation of corporate governance, transformational leadership style and work motivation to the RSUD $X$ performance; There is a partial positive significant affect between the implementation of corporate governance and transformational leadership style on work motivation at RSUD X. Managerial implications: By improving SIMRS, communication systems and remuneration systems.
\end{abstract}

Keywords: Corporate Governance Implementation, Transformational Leadership Style, Work Motivation, Hospital Performance.

\section{INTRODUCTION}

Public organizations are organizations which established to fill the needs of the community for public services. Hospital is one of the public organizations whose performance is assessed, and this also applies to RSUD X. RSUD X is an governmentowned hospital with management as a Regional Public Service Agency (BLUD) and officially opened for public on August 15, 2005. The services provided are limited to 11 specialist outpatient services, Emergency Units, ambulance and medical support. From 2016 to 2018, RSUD Bekasi has won the Best Public Service award in a row. In 2018, RSUD 
Bekasi passed accreditation from the National Hospital Accreditation Standard (SNARS) with Plenary results (5 Stars).

RSUD $\mathrm{X}$ as a public hospital that provides health services for patients is required to served according to standards which set by Ministry of Health of the Republic of Indonesia and also the Hospital Accreditation Commission and strive to carry out corporate governance optimally. Based upon this, RSUD X need to fill the indicators according to the minimum service standards for each functional unit which also a performance indicator that monitored regularly by hospital management, either in the form of an internal report every month or every year, as well as part of the assessment for overall hospital accreditation. The performance assessment of RSUD X were performed annually by the Internal Supervisory Unit (SPI) which then reports it to the hospital director and then to the Regional Government. The performance appraisal is in the form of financial and non-financial aspects. According to the evaluation of the performance report of RSUD X in 2019, it can be seen that Financial aspect performance achievement was 22.35 from weight of 30.00 or equivalent to $74.50 \%$ and service performance achievement of 55.86 from a weight of 70.00 or reached $79.80 \%$. These results was indicate that the performance of RSUD X still not met the standards set by Regional Government.

Build on from the interviews with leaders and employees, it was found that RSUD X has implemented the principles of corporate governance, namely transparency, accountability, responsibility, independence, and fairness, although still not yet optimal. According to the employee satisfaction survey at RSUD X in 2018, 66\% of employees were satisfied with the interaction of leaders with their subordinates, $26 \%$ were very satisfied, however, there were still have $8 \%$ who were dissatisfied and very dissatisfied. In 2018 RSUD X's employee satisfaction survey also found that $65 \%$ of employees were satisfied with work motivation, $19 \%$ were very satisfied and 16\% were dissatisfied and very dissatisfied. Derived from the results of interviews and initial data collection to the leadership and 15 employees, it was also found that $93.3 \%$ of employees stated that their leaders had good abilities in making decisions, motivating employees and being responsible for what they had decided. The current workplace feels comfortable, safe and quiet and the means of communication are fulfilled as an option for $73.3 \%$ of employees. Good relations with fellow co-workers are now also what employees expect, beside to sufficient income and gaining the trust from the leaders.

Previous research stated that the implementation of good corporate governance had a significant positive affect to the performance (Kesuma \& Nurhayati, 2020), but research from Hidayah (2008) found that there was no correlation between corporate governance and performance. Research from Risambessy et al. (2012) found that transformational leadership style had a significant affect to motivation and performance. Different research found that transformational leadership style had no significant affect to motivation and performance (Nurhuda et al., 2019). Work motivation is the most dominant variable which affecting performance (Suandana, 2018) as it stated by Nurhuda et al (2019). 
Based on the reasons that have been described, the authors were interested in conducting research on these matters with the title "The Mediating Role from Work Motivation towards the Implementation of Corporate Governance and RSUD X's Performance". This research is expected to gained knowledge and insight in the development of good hospital governance (good corporate governance).

\section{THEORETICAL REVIEW}

\section{Hospital Performance}

Hospital performance can be defined as the achievement of specific goals, both medically and managerially in hospital services (McCann et al., 2014). Performance which often referred as performance and also could be called as result which means with what has been produced by individual employees (Fischer, 1987). Performance is the result of work that has a strong link to the organization's strategic goals, customer satisfaction and contributes to the economy (Wibowo, 2007). Regulation from the Directorate General of Treasury of the Ministry of Finance of the Republic of Indonesia Number Per-34/PB/2014 stated that the measurement of hospital performance can include financial and non-financial aspects. The financial aspect is in the form of financial ratios and financial management compliance, while the non-financial aspect is in the form of service quality and grade and benefits to the community.

\section{Corporate Governance Implementation}

Corporate governance is a process of supervision and control intended to ensure that management does things according to the shareholders expectation (Parkinson, 1994). Good governance is a form of managing an organization to achieve goals based on the principles of good governance. Some of the principles regarding good governance were included the Organization for Economic Cooperation and Development (OECD), namely: Fairness, Transparency, Accountability and Responsibility. The Forum for Corporate Governance in Indonesia (FCGI) revealed the principles of good governance as Fairness, Disclosure, Transparency, Accountability and Responsibility. Corporate governance is an process of supervision and control which intended to ensure that management does things right according to the wishes of the shareholders (Parkinson, 1994). Good governance is a form of managing an organization to achieve goals based on the good governance principles. Some of the principles relates to good governance are include the Organization for Economic Cooperation and Development (OECD) namely: Fairness, Transparency, Accountability, and Responsibility. The Forum for Corporate Governance in Indonesia (FCGI) revealed the principles of good governance as Fairness, Disclosure, Transparency, Accountability, and Responsibility. Good corporate governance is a universal principle, so it can be found in cultures everywhere. The thing that distinguishes the practice of good corporate governance in a country is as a system that need to adapt to the legal system, the circumstances and developments of progress and the culture of the nation itself (Dwija Putri et al., 2017).

\section{Transformational Leadership Style}


Robbins in Irnawati \& Prasetyo (2020) says that leadership is an ability to affecting the groups in order to achieve the goals. Good leadership will be a liaison between employees and organization to create synergy and its employee motivation (Riyanto et al., 2021). Transformational leadership style is a leadership model by changing the personal values of followers to support the vision and goals of the organization by fostering an environment in which relationships can be formed and by building a climate of trust in which the vision can be spread (Bass \& Avolio, 2006). Leaders who have a transformational leadership style will have the characteristics of idealized influence, inspirational motivation, intellectual stimulation and individualized consideration (Avolio et al. in Stone et al., 2004).

\section{Work Motivation}

Motivation is a certain psychological state in a person that arises because of the urge to meet needs. According to Herzberg (2006), work motivation is a person's attitude towards his/her work in the form of an inner drive to carry out their duties properly, so that a sense of satisfaction arises in working so that their goals are achieved. Motivation will emerge when individuals seek optimal satisfaction for certain needs (Giauque et al. in Riyanto \& Prasetyo, 2021). Herzberg (2003) in his motivator and hygiene theory declared that there are several factors that act as motivators for employees, namely achievement, progress, the work itself, recognition and growth. Furthermore, work dissatisfaction factors included money/salary, working conditions, relations with colleagues, relations with superiors, company policies and administration and security (Herzberg, 2003).

\section{Previous Research}

In a research which conducted by Kesuma \& Nurhayati (2020) it was found that the better implementation of corporate governance principles had a significant affect to hospital performance. Potu (2013) found that leadership, motivation and work environment simultaneously had a positive and significant affect on performance. Irnawati \& Prasetyo (2020) found that transformational leadership had a positive and significant affect to the achievement of government organizational performance. Adhi \& Aima (2021) found that transformational leadership had a positive correlation to work motivation and government organizations' performance, work motivation has an impact towards fixing government organizational performance and can act as an mediator for transformational leadership. Katharina (2020) found that the right implementation of corporate governance will be able to increase employee motivation.

\section{Theoretical Framework and Hypothesis}

According to this phenomenon, theoretical research and several prior research that have been described above, the framework and hypothesis that could be drawn from this research are: 


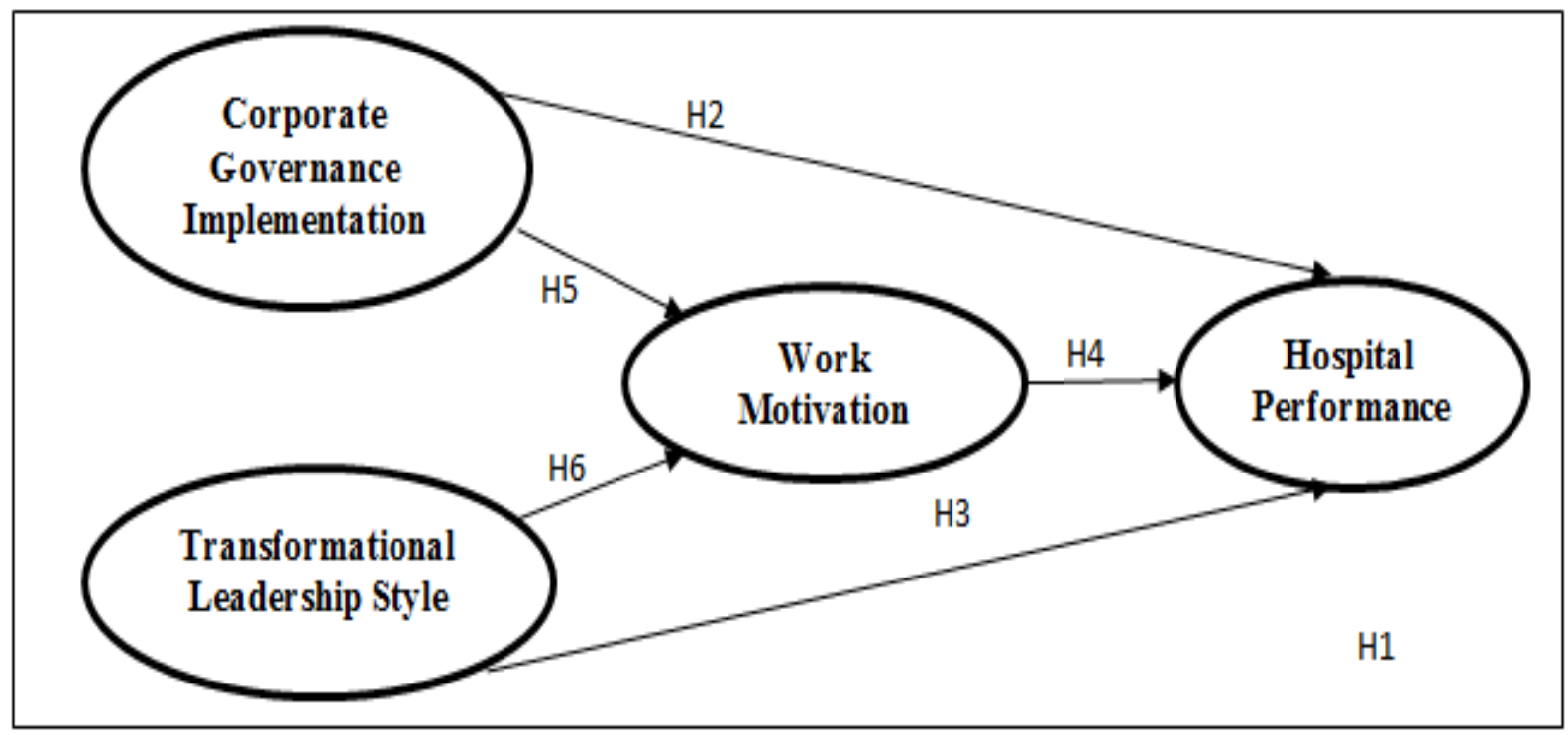

Figure 1. Theoretical Framework

H1: There is a simultaneously affect between the implementation of corporate governance, transformational leadership style and work motivation on the performance of RSUD X.

$\mathrm{H} 2$ : There is a significant affect from the implementation of corporate governance on the performance of RSUD X.

H3: There is a significant affect which occured from transformational leadership style on the performance of RSUD X.

H4: There is a significant affect which occured from work motivation on the performance of RSUD X.

H5: There is a significant affect from the implementation of corporate governance on work motivation at RSUD X.

H6: There is a significant affect from transformational leadership style on work motivation at RSUD X.

\section{RESEARCH METHODS}

This research was conducted at the RSUD X during period April-June 2021. The variables in this research were included two independent variables $(\mathrm{X})$, namely corporate governance implementation (X1) and transformational leadership style (X2). While the dependent variable is hospital performance $(\mathrm{Y})$ and the intervening variable is motivation $(\mathrm{Z})$. Hypothesis test in this research were done by reference to causality associative. The population of this research were all employees of the State Civil Apparatus (ASN) at the RSUD $X$ which consisted $84.23 \%$ of service personnel and $15.77 \%$ of management/administration personnel with a total of 241 people. In this research there are 22 indicators, thus the number of samples to be taken is 5-10 times 22 , which is $110-220$ samples. The maximum number according to the rule of thumb is 200 samples, so the sample to be taken is the maximum number, which is 200 samples (Hair et al., 2019). The sampling technique is probability sampling by disproportionate stratified random sampling. The data collection technique used was instruments in the form of questionnaires, data from hospital performance audit work papers and library research. 
Those measurement used the calculation from the total score of the hospital performance variable and Likert Scale for the implementation of corporate governance, transformational leadership style, dan work motivation. The data analysis of this research consisted of descriptive statistical analysis and inferential statistical analysis. The descriptive statistical analysis from this research used the three box method, while the inferential statistical analysis used AMOS-SEM.

\section{RESULT AND DISCUSSION}

\section{Characteristics of Respondents}

According to the results from questionnaire, the characteristics of the respondents in this research were mostly female $(68.5 \%)$, had a bachelor's degree education (40\%), worked as health workers $(88 \%)$ and had a working period of $>5$ years $(78.5 \%)$. This indicates that the majority of RSUD X employees are highly educated and experienced women who have educational backgrounds according to their fields, so that they can carry out their duties and functions in the organization very well.

\section{Research Instrument Test}

According to the validity test result, it shows that there are 72 variables indicators observed in the exogenous latent variable and 4 endogenous variables that have passed the validity test, because of the 76 indicator variables, all loading factors value $>0.50$. Thus the research instrument of 76 indicators has met the validity test requirements, so it can be continued using a research model by measuring the dimensions of each variable.

In accordance to the measurement test results, it shows that all dimensions and research variables have loading factors $>0.50$ and $\mathrm{CR}>0.7$ and $\mathrm{VE}>0.5$. Thus, the exogenous and endogenous latent variables met the validity and reliability test requirements.

Table 1. Data Quality Test Results

\begin{tabular}{|l|c|c|c|c|}
\hline \multirow{2}{*}{ Latent Variable } & \multirow{2}{*}{ Estimate } & \multirow{2}{*}{ Standard Loading } & \multicolumn{2}{c|}{ Reliability } \\
\cline { 4 - 5 } & & & $\mathrm{CR} \geq 0.70$ & $\mathrm{VE} \geq 0.50$ \\
\hline Corporate Governance Implementation $\left(\mathrm{X}_{1}\right)$ & $0.540-0.891$ & $0.681-0.990$ & 0.836 & 0.621 \\
\hline Transformational Leadership Style $\left(\mathrm{X}_{2}\right)$ & $0.775-0.903$ & $0.850-0.925$ & 0.924 & 0.793 \\
\hline Work Motivation $(\mathrm{Z})$ & $0.619-0.942$ & $0.671-0.844$ & 0.887 & 0.595 \\
\hline Hospital Pefformance $(\mathrm{Y})$ & $0.582-0.866$ & $0.604-0.854$ & 0.751 & 0.570 \\
\hline
\end{tabular}

\section{Descriptive Analysis}

Descriptive analysis in this research used Three Box Method index number. To get the tendency of respondents' answers to each variable, it will be categorized into a range of scores based on the calculation of the three box method. The resulting index number is 200 , while the range of the scale for each criterion is 53.3. According to the analysis results, it is known that the average value for the variable of implementing corporate governance is 160.08 and included in the "High" category, meaning that respondents have a high perception of the implementation of corporate governance at RSUD X. The highest index was found in the CG24 indicator with an index value of 171.20 with an assessment point that "Employees' 
rights to receive incentives (employee benefits) and other permitted income are regulated by applicable regulations" mostly answered favorably/agreed by respondents. While the lowest index was the CG03 indicator with an index value of 140.40 by an assessment point that "Financial reports are presented openly and accurately every year".

The average value for the transformational leadership style variable is 159.53 and was included in the "High" category, meaning that respondents have a high perception of transformational leadership style at RSUD X. The highest index was found in the GK01 indicator with an index value of 163.40 by an assessment point that "The leader motivates me to work better" mostly answered favorably/agreed by the respondents. While the lowest index was found in the GK16 indicator with an index value of 155.40 by an assessment point that "The leader treats me as a personal individual, not just as a member of a work group".

The average value for work motivation variable is 159.29 and was included in the "High" category, meaning that the respondent has a high perception of work motivation at RSUD X's employees. The highest index was found at the MK23 indicator with an index value of 167.40 by an assessment point that "My relations with my co-workers is good and harmonious" mostly answered favorably/agreed by the respondents. While the lowest index was the MK22 indicator with an index value of 150.40 by an assessment point that "I feel enough with the incentives I receive".

The average value for hospital performance variable was 154.35 and included in the "High" category, meaning that the perception of hospital performance at RSUD X is high. The highest index was found in the Y3 indicator with an index value of 156.80 by an assessment point that the service quality of the RSUD $\mathrm{X}$ is better compared to other indicators on the hospital Performance variable.

The results from the description of attitudes in behavior indicate that all variables have a positive response. If you look further through statement items in the questionnaire, you will find an unfavorable response. In the variable of corporate governance implementing, it was known that respondents felt that financial statements were not presented openly and accurately every year, but still believed in the activities carried out by management, thus it can be concluded that the governance at RSUD X still good. In the transformational leadership style variable, there are still employees who consider the leader treating him as a personal individual not only as a member of a work group, but still obedient in carrying out their duties, thus it can be assumed that the leader performed their leadership collaboratively. In the work motivation variable, some of employees feel that the incentives that they received still not enough, but still enthusiastic in carrying out their duties, thus it can be interpreted that employee's work motivation is good.

\section{Structural Model Fit Test}

Elicited from the calculation results, it is seens that all indicators of the critical ratio value are below \pm 2.58 meaning that the data is normally distributed. Then, the AMOS output 
result in this research were also showed that there was no data that had $\mathrm{p} 1$ and $\mathrm{p} 2$ values < 0.001 , so it means that there were no data outliers in this research.

Based on the Goodness of Fit Test output, 10 of the 10 model criteria indicate a fit model, it can be said that the structural model in this research can be declared as good (good fit).

Table 2.Goodness of Fit Test Results

\begin{tabular}{|l|l|c|c|}
\hline GOF Index & \multicolumn{1}{|c|}{ Cut-Off Value } & Output & Information \\
\hline Probability & p $>0,05$ & 0.179 & Fit \\
\hline RMSEA & RMSEA $\leq 0,08$ & 0.022 & Fit \\
\hline RMR & RMR $<0,05$ & 0.011 & Fit \\
\hline GFI & GFI $\geq 0,9$ & 0.925 & Fit \\
\hline AGFI & AGFI $\geq 0,8$ & 0.887 & Fit \\
\hline CMIN/DF & CMIN/DF $\leq 2$ & 1.099 & Fit \\
\hline TLI & TLI $\geq 0,95$ & 0.993 & Fit \\
\hline CFI & CFI $\geq 0.95$ & 0.995 & Fit \\
\hline NFI & NFI $\geq 0,90$ & 0.949 & Fit \\
\hline IFI & IFI $\geq 0.90$ & 0.995 & Fit \\
\hline
\end{tabular}

\section{Hypothesis Test}

From this analysis results, it shows that the probability value(significance) is 0.179 ( $>$ $0.05)$ and $\mathrm{R}^{2}$ value is 0.641 . It can be interpreted that there is a simultaneous affect between the corporate governance implementation, transformational leadership style and work motivation towards the performance of RSUD X with a large affect of $64.1 \%$, while the remaining $35.9 \%$ was determined by other variables outside this research. From the direct influence analysis result, it is known that:

1) There is a positive and significant affect between corporate governance implementation towards hospital performance. This indicated by the value of estimate $=0.189$ which sign a positive correlation and has a significant affect because of the P-Values $=0.003$, meaning that is smaller than $(\alpha=0.05)$.

2) There is a positive and significant affect between transformational leadership style on hospital performance. This indicated from the value of estimate $=0.191$ which sign a positive correlation and has a significant affect because the value of P-Values $=0.022$, meaning it is smaller than $(\alpha=0.05)$.

3) There is a positive and significant affect between work motivation on hospital performance. This is indicated by the value of estimate $=0.375$ which sign a positive correlation and has a significant affect because the P-Values $=0.001$, meaning it is smaller than $(\alpha=0.05)$.

4) There is a positive and significant affect between the corporate governance implementation on work motivation. This indicated by the value of estimate $=0.118$ which sign of a positive correlation and has a significant affect because the P-Values $=0.028$, meaning it is smaller than $(\alpha=0.05)$.

5) There is a positive and significant affect between transformational leadership style on work motivation. This is indicated by the value of estimate $=0.690$ which sign of a positive correlation and has a significant affect because the P-Values $=0.001$, in other word it is smaller than $(\alpha=0.05)$. 


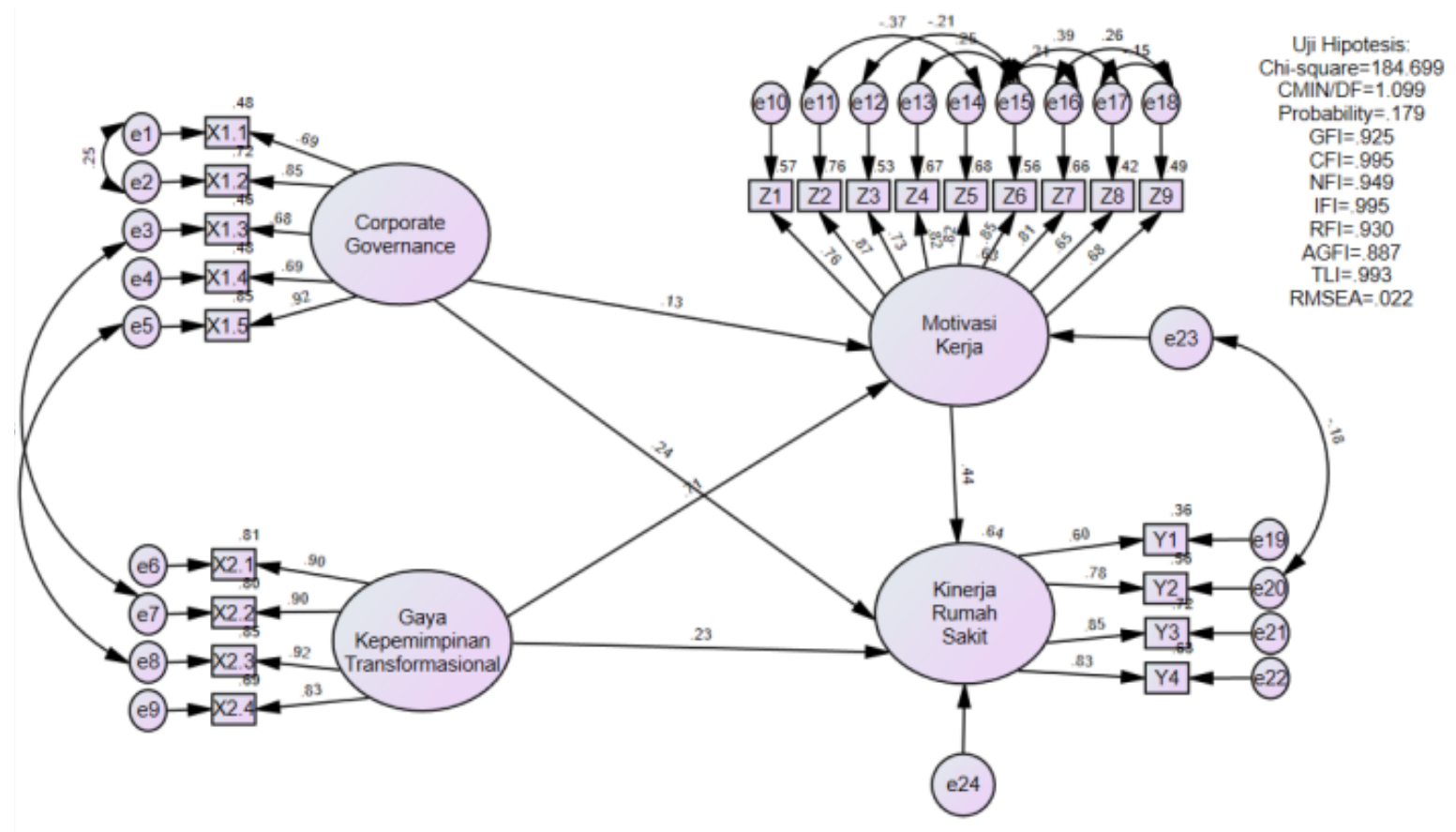

Figure 2. Structural Model

Table 3. Hypothesis Test Results

\begin{tabular}{|c|c|c|c|c|c|}
\hline Relationship Between Construct & Estimate & S.E. & C.R. & P & Information \\
\hline Hospital Performance $<-$ Corporate Governance Implementation & 0.189 & 0.063 & 3.008 & 0.003 & Accepted \\
\hline Hospital Performance $<-\quad$ Transformational Leadership Style & 0.191 & 0.083 & 2.292 & 0.022 & Accepted \\
\hline Hospital Performance $<-c \quad$ Work Motivation & 0.375 & 0.091 & 4.143 & 0,001 & Accepted \\
\hline Work Motivation $<-$ Corporate Governance Implementation & 0.118 & 0.054 & 2.196 & 0.028 & Accepted \\
\hline Work Motivation $<-\quad$ Transformational Leadership Style & 0.690 & 0.073 & 9.467 & 0.001 & Accepted \\
\hline R-Square of Work Motivation & \multicolumn{3}{|c|}{0.630} & & Accepted \\
\hline R-Square of Hospital Performance & \multicolumn{3}{|c|}{0.641} & Accepted \\
\hline
\end{tabular}

\section{Discussion}

The implementation of corporate governance, transformational leadership style and work motivation simultaneously affect the RSUD X Performance

The research outcomes that performed was indicate that the corporate governance implementation, transformational leadership style, and work motivation had a simultaneous affect on the performance of RSUD X. This means that The corporate governance implementation, transformational leadership style, and work motivation increases, it will affect to the increase of performance from RSUD X and conversely if the implementation of corporate governance, transformational leadership style and work motivation is low, then the RSUD X performance will decrease aswell. Hospital performance can be defined as the achievement of specific goals, both medically and managerially in hospital services. This performance shown not only quality, but also other factors such as cost of care, access to care and the connection between satisfaction and patient expectations. Good performance could be 
identified as the provision of cost-effective, good quality and appropriate health services, resulting in patient satisfaction (McCann et al., 2014). The Achievement from the government agency performance could not be separated from the implementation of good corporate governance. Those Efforts by the Government of the Republic of Indonesia to reach good governance and carry out fundamental reforms and changes to the government administration system are through bureaucratic reform. Fundamental changes made regarding institutional (organizational) aspects, management and human resources (Riyanto \& Prasetyo, 2021). The good hospital governance will be seen if every activity carried out meets the principles of implementing corporate governance, namely transparency, accountability, responsibility, independence, fairness and equality. The existence of an information system which easily accessible to the public is one example of the implementation of transparency. Besides to the implementation of corporate governance, a government agency need to pay attention to the leadership style applied in organization environment, because good leadership will be a liaison between employees and organization so as to create synergy and create employee motivation (Riyanto et al., 2021). Leaders are expected to be role models in every action and always motivate employees. Therefore, the government agencies need to ensure the essence of transformational leadership which appears in the process of inspiring, developing, and empowering followers (Yukl, 2015). With the empowerment of these employees will help increase the work motivation and will have an impact to improving organizational performance.

\section{The implementation of corporate governance affects to the RSUD $X$ performance}

The results from this research shows that the implementation of corporate governance had a positive and significant affect to the performance of the RSUD X. This means that if the application of corporate governance increases, it will improve the performance of RSUD $\mathrm{X}$ and conversely if the implementation of corporate governance is low, the performance of RSUD X will decrease aswell. Corporate governance is an process of supervision and control which intended to ensure that management did something in accordance with the shareholders expectation(Parkinson, 1994). Corporate governance has a function as a company's internal control system which aims to manage risk in order to meet its business purposes. The existence of good corporate governance will help a company improve a cleaner, transparent and professional management work pattern so that it will improve the organizational performance. This results were confirmed the research of Kesuma \& Nurhayati (2020) who found that the implementation of the good corporate governance principles has a significant positive affect to hospital performance. In other words, the implementation of corporate governance in a government agency will increase the value of the agency in the eyes of public. This happens because the implementation of corporate governance will helps hospital management in arranging, operating and running their business properly, Thus it can be used as a tool of interaction that regulates between structures and mechanisms which ensure control but still encourages efficiency and performance in hospitals. The implementation of corporate governance can improve the value of hospitals by improving hospital performance through four aspects of performance measures which included financial ratios, financial management compliance, service quality 
and quality assurance as well as benefits to the community if its run good and consistent that will make all hospital activities run effectively and efficiently.

\section{Transformational leadership style affects to the RSUD $X$ performance}

The research findings showed that the transformational leadership style had a positive and significant affect to the performance of RSUD X. This means that if the transformational leadership style increases, it will increase the RSUD X performance aswell and conversely if the transformational leadership style is low, then the performance of RSUD X will decrease. Transformational leadership is a comprehensive and integrated leadership ability which needed for individuals, groups, and organizations to produce transformations marked by changes at every stage of activity (Hacker \& Robberts, 2004). The transformational leadership style is used by a manager when they wanted a group to expand and perform beyond status and achieve an entirely new set of organizational goals. Leaders who have a transformational leadership style will be able to unite all their subordinates and capable to change the beliefs, attitudes, and personal goals of each subordinate in order to achieve goals, even beyond the goals set. This results were confirmed the research of Irnawati \& Prasetyo (2020) and Adhi \& Aima (2021) who found that the transformational leadership style had a positive and significant affect to the achievement of government organizational performance. The transformational leadership style applied by the leadership at the RSUD X will assist the agency in optimally transforming organizational resources in order to reach a meaningful goals according to predetermined targets so that it will improve the performance of the agency.

\section{Work motivation affects to the RSUD $X$ performance}

The research outcomes showed that work motivation had a positive and significant affect on the performance of RSUD X. Meaning that if work motivation increases, it will increase the RSUD X performance aswell and conversely if work motivation is low, then the performance of RSUD X will decrease. As it stated by Herzberg, work motivation is an person's attitude towards their work in the form of an inner drive to carry out duties with well, so that a sense of satisfaction will arises in working and that goal are achieved, with factors which affect it are achievement, recognition, work itself, progress, responsibilities, individual potential development, administration and policies, salaries and interpersonal relations. Mangkunegara in Febriyarso \& Ruslan (2021) suggests that motivation is an condition or energy that moves employees either directed or indirected to achieve the company's organizational goals. Motivation will emerge when individuals seek optimal satisfaction for certain needs (Giauque et al., 2011 in Riyanto \& Prasetyo, 2021). The motivation that exists in a person will encourage someone to realize a behavior which useful in achieving the goal of self-satisfaction. People want to work to fill their needs, both conscious needs and unconscious needs, so it will improve personal and organizational performance. This results were confirm the research from Adhi \& Aima (2021) who found that work motivation has a positive and significant affect to the achievement of government organizational performance. By the work motivation shown on the RSUD X employees, it will encourage employees to do as much as possible in performing their duties because they 
believe that with the success of the organization in achieving its goals and various targets, the personal interests of the members of the organization will also be retained.

\section{The implementation of corporate governance affects to the work motivation at RSUD X}

The research shows that the corporate governance implementation has a positive and significant affect towards work motivation. Meaning that if the implementation of corporate governance increases, it will increase the work motivation aswell and it does conversely if the implementation of corporate governance is low, then work motivation will decrease. Good corporate governance is a form of controlling an organization to achieve goals according to the principles of good governance. Good corporate governance is the principles that underlie a process and mechanism for managing a company based on laws and regulations and business ethics. The implementation of corporate governance will help agencies build trust and act responsibly, so that agencies will have high integrity and increase work motivation. This results were confirm Katharina's research (2020) who found that the implementation of good corporate governance will be able to increase the employee motivation. This proves that the implementation of good corporate governance will make it easier for RSUD X to map each company's operational activities, so they will be able to see the details needed by the agency in increasing the work motivation of its employees.

\section{Transformational leadership style affects to the work motivation at RSUD X}

The research outcomes shows that transformational leadership style has a positive and significant affect on work motivation. Meaning that if the transformational leadership style increases, it will increase work motivation and it does conversely if the transformational leadership style is low, then work motivation will decrease. Transformational leadership is a process of inspiring and empowering individuals, groups and organizations. Bass \& Riggio (2006) declared that transformational leadership is an emphasizes intrinsic motivation and also the development of subs, because motivating the subs is one of the characteristics of transformational leadership. This results were in line with the research of Adhi \& Aima (2021) who found that transformational leadership style has a positive and significant affect towards employee motivation. This proves that the implementation of transformational leadership style will help the leaders to motivate and inspire those around them by explaining that their work is important and full of challenges. How to motivate can be done by various methods, for example the needs method, which is to meet the main needs of subs such as physical, security, social, esteem, and self-actualization needs. Meeting needs can also be done by creating justice as outlined in a permanent system, by providing opportunities to contribute in advance to the organization. Meanwhile, to generate inspiration can be done by evaluating the failures and successes that have been achieved, encouraging learning processes such as discussions, reading, comparative studies and so on.

\section{Research Findings}

This research has found that work motivation had the greatest direct impact to the performance of RSUD X. While the transformational leadership style had the greatest direct impact to the employees work motivation at RSUD X. 
The indirect affect from the implementing corporate governance on hospital performance was higher than the direct affect ones. These results was indicate that to improve the performance of RSUD X, the role of work motivation is needed as an mediating variable. Meanwhile, the direct affect from transformational leadership style on hospital performance is higher than its indirect affect. Which means that to improve the performance of RSUD X, the role of work motivation as an mediating variable is not required.

\section{CONCLUSION, IMPLICATION, AND SUGGESTION Conclusion}

The Conclusion which obtained from this research is that the implication of corporate governance, transformational leadership style and work motivation have been shown to have a simultaneous affect to the RSUD X performance through work motivation as the variable that has the greatest direct affect on it. These results also shows that the implementation of corporate governance were proven to have a positive and significant affect to the performance of RSUD X with indirect affect which being higher than its direct effect. This research results were also found that transformational leadership style proved to have a positive and significant affect on the performance of RSUD X. In addition, the results showed that work motivation has proven to have a positive and significant affect on the RSUD X performance and was an important as a mediator to relates the impact of implementing corporate governance to RSUD X Performance. Then, these research results show that the implementation of corporate governance has a positive and significant affect to the work motivation and also shows that transformational leadership style has a positive and significant affect to the work motivation.

\section{Managerial Implications}

The research results were indicate that the implementation of corporate governance at RSUD X is good, although not enough perfect in the distribution of information, so there are still have an employees who feel that they lack information about open and accurate financial reporting. Management needs to improve the Hospital Management Information System (SIMRS) so that information is widely distributed, thus management can continue to evaluate performance and ensure transparency goes well.

The leadership at RSUD X shown if the transformational leadership style went well, but there are still employees who feel they are only treated as members of a work group and were not given personal appreciation by the leaders. Leaders and management are expected to improve the communication system at this hospital by involving all employees individually in each section of RSUD X, so that the employees will be more collaborative and follow every step and the existing rules for the betterment of the organization.

Hospital X employees have good work motivation but there are still have an employees who feel that the incentives they were received are not commensurate with the work and tasks given. Management needs to improve the remuneration system to rationalize the incentives at hospitals in an effort to motivate employees to improve their work performance and productivity, Thus the performance of RSUD X would be more optimal. 


\section{Suggestion}

Elicited from the research results that has been done, here are some suggestions that researchers can give, namely:

1) Hospital leaders and management were expected to maximize the role of Internal Supervisory Unit (SPI), such as in providing input that can maintain and improve the quality of governance in the implementation of duties and functions of government agencies (hospitals) so good corporate governance could be created with the principles of transparency, accountability, responsibility, independence, fairness and equality.

2) Leaders and management were advised to improve the hospital management information system regarding staffing lists, financial reports and those reports related to issues which faced by the hospital so that every information can be known by all employees. Evaluation of financial performance by implementing digital transformation can be done, so the financial statements of RSUD X can be seen and monitored by all employees through official platform which has been provided.

3) Hospital leaders and management were also advised to improve their closer relations with employees through effective communication by opening direct lines of communication, thus creating a collaborative attitude and providing positive feedback from both management and employees itself.

4) Hospital leaders and management are advised to provide opportunities for employees to develop their potential and abilities by choosing innovations that are found by employees in their work so that they can increase employee work motivation. The leadership's attention to employee performance in carrying out their work by implementing a system of reward and punishment (award and punishment), can be a suggestion that needs to be done as well, in addition to paying more attention to employee careers and fostering employee confidence by providing opportunities to participate in the selection of career advancements. so that employees will work better and be able to complete work goals in accordance with the time allotted.

5) Future research were expected to explore further into the variables which possible have an affect to hospital performance, such as the variable of clinical governance implementation which is a series of hospital governance. The high direct impact caused by work motivation on hospital performance which found in this research were opens the possibility of other influences from other variables, namely compensation, work satisfaction, work discipline, organizational citizenship behavior, employee engagement and organizational commitment.

\section{BIBLIOGRAPHY}

Adhi, B., \& Aima, M. H. (2021). The Impact Of Transformational Leadership And Compensation Towards Motivation And Its Implications On Organizational Performance At The Education And Training Center Of The Ministry Of Communication And Information. Dinasti International Journal of Management Science, 2(5), 766-776.

Bass, B. M., \& Avolio, B. J. (1993). Transformational leadership and organizational culture. Public administration quarterly, 112-121. 
Bass, B. M., \& Riggio, R. E. (2006). Transformational Leadership, Second Edition. New Jersey: Lawrence Erlbaum Associates, Publishers

Febriyarso, E. B., \& Ruslan, S. (2021). The Importance role of Competency-Based on Training, Motivation and Organizational Culture in Improving the Employee Performance in Education and Research Training Centers and HR Development aAt The Ministry of Communication and Informatics. Dinasti International Journal of Education Management And Social Science, 2(4), 642-653. https://doi.org/10.31933/dijemss.v2i4.827

Hacker, S., \& Robberts, T. (2004). Transformational Leadership (Creating organization of meaning). Wisconsin: Quality Press.

Hair, J. F., Black, W. C., Babin, B. J., \& Anderson, R. E. (2019). Multivariate Data Analysis. Hampshire: Cengage.

Harsono, A. D., Indrawati, R., \& Jus'at, I. (2021). Situational Leadership Style Supports the Performance of Doctors in the Military Based Hospital. European Journal of Business and Management Research, 6(2), 118-126. https://doi.org/10.24018/ejbmr.2021.6.2.780

Herzberg, F. (2003). One More Time: How Do You Motivate Employees? In Harvard Business Review. https://doi.org/10.1007/978-1-349-02701-9_2

Indrawati, R., Ruswanti, E., \& Amalia, N. S. (2021). The Importance of Employee Engagement in Mediating the Improvement of Staff Performance at the Hospital. International Journal of Nursing and Health Services (IJNHS), 4(3), 313-324.

Irnawati, J. E., \& Prasetyo, J. H. (2020). The Influence Over the Transformational of Leadership Style, the Organizational Culture, and Employee Empowerment towards Achievement of Organizational Strategies in one the Central Government Organization. International Journal of Innovative Science and Research Technology, 5(3), 917-927. https://ijisrt.com/assets/upload/files/IJISRT20MAR333.pdf

Katharina, N. (2020). Pengaruh Pelaksanaan Good Corporate Governance Terhadap Motivasi Kerja Pada Universitas Sumatera Utara. Akuntansi Prima, 1(2). https://doi.org/10.34012/japri.v10i1.986

Kesuma, I. M., \& Nurhayati, Y. (2020). Pengaruh Penerapan Good Corporate Governance Dalam Meningkatkan Kinerja Rumah Sakit di Kota Lubuklinggau dan Kabupaten Musi Rawas Dengan Pendekatan Balanced Scorecard. Jurnal Ecoment Global, 5(1), 12. https://doi.org/10.35908/jeg.v5i1.804

McCann, J. T., Graves, D., \& Cox, L. (2014). Servant Leadership, Employee Satisfaction, and Organizational Performance in Rural Community Hospitals. International Journal of Business and Management, 9(10). https://doi.org/10.5539/ijbm.v9n10p28

Parkinson, J. (1994), Corporate Power and Responsibility. Oxford University Press. Oxford.

Peraturan Diroktorat Jenderal Perbendaharaan Kementerian Keuangan Republik Indonesia Nomor Per-34/PB/2014. (2014). Pengukuran Kinerja Rumah Sakit. Jakarta.

Potu, A. (2013). Kepemimpinan, Motivasi, Dan Lingkungan Kerja Pengaruhnya Terhadap Kinerja Karyawan Pada Kanwil Ditjen Kekayaan Negara Suluttenggo Dan Maluku Utara Di Manado. Jurnal Riset Ekonomi, Manajemen, Bisnis Dan Akuntansi, 1(4), 1208-1218. https://doi.org/10.35794/emba.v1i4.2894 
Riyanto, S., \& Prasetyo, J. H. (2021). Factors affecting civil servant performance in indonesia. International Journal of Entrepreneurship, 25(5), 1-15. https://www.abacademies.org/articles/Factors-Affecting-Civil-Servant-Performance-inIndonesia.pdf

Riyanto, S., Janiah, S., \& Prasetyo, J. H. (2021). A strategy to strengthen the organizational citizenship behaviour of steel industry's employee in indonesia. Academy of Strategic Management Journal, 20(3), 1-14. https://www.abacademies.org/articles/A-strategy-tostrengthen-the-organizational-citizenship-behaviour-of-steel-industrys-employee-inindonesia-1939-6104-20-3-784.pdf

Yukl, G. (2015). Kepemimpinan dalam Organisasi. Indeks. Jakarta. 